\title{
Mathematical Modeling of Solar Photovoltaic Module to generate Maximum Power Using Matlab/Simulink
}

\author{
aAmusat R. O. , bShodiya S, 'Ngadda Y.H. \\ a, cDepartment of Physics, University of Maiduguri, Borno 1069, Nigeria \\ bepartment of Mechanical Engineering, University of Maiduguri, Borno 1069, Nigeria \\ Received 12 December 2020; accepted 16 March 2021
}

\begin{abstract}
Modeling is a basic tool of the real system simulation in translating the Mathematical results into real life. In this study, the Modeling and simulation of photovoltaic Module type PS-P310-36 were developed, and maximum power was obtained. The output I $-\mathrm{V}$ and $\mathrm{P}-\mathrm{V}$ curves of the model were studied and analyzed under different irradiance $\left(200 \mathrm{~W} / \mathrm{m}^{2}, 400 \mathrm{~W} / \mathrm{m}, 600\right.$ $\mathrm{W} / \mathrm{m}^{2}, 800 \mathrm{~W} / \mathrm{m}$, and $1000 \mathrm{~W} / \mathrm{m}^{2}$ ) at a constant temperature of $25^{\circ} \mathrm{C}$. The model attained maximum power of 308, 251.6, 191.4, 129.2, and $64.74 \mathrm{~W}$ at $1000,800,600,400$, and $200 \mathrm{~W} / \mathrm{m}^{2}$ irradiance, respectively. The model results agreed with the characteristics curves of the PV module of previous similar PV studies. The proposed model will serve as quick tools for designers in obtaining the maximum power of PV at distinct irradiance. However, for a more accurate design, more information is needed.
\end{abstract}

\section{KEYWORDS}

Matlab/Simulink

PV Model

Irradiance

I-V and P-V curves

\section{INTRODUCTION}

Rising fossil fuel costs, environmental concerns relating to global climate change, and Government policy significantly increase our Nation's dependence on renewable energy, such as the Sun (light and heat), water, and wind, which are inexhaustible generate electricity. Renewable energy, such as solar energy, has gained attention because of its direct conversion of light energy into electrical power without any harmful environmental impacts. Many researchers in various ways have developed models that can predict the potential of this renewable energy. Amusat et al.(Garba, Amusat, and Ngadda 2016) developed empirical models that estimate the monthly average daily global solar radiation of Maiduguri, Borno State, Nigeria. The model that best fit the data was chosen by comparing the regression of the coefficient of the models. Abdullahi et al.(Madu, Shodiya, and Toyin 2018) developed a model using Gunn Bellan radiation integration. This model was used to assess the potential of solar radiation for electricity generation in Potiskum, Yobe State, Nigeria. Luqman et al.(Shodiya et al. 2016) developed a preassessment model using single variable and multivariable regression techniques of Angstrom type. The model was used to evaluate the total solar radiation reaching a horizontal surface in Maiduguri, Borno State, Nigeria. 
Mathematical Modeling of PV module for the evaluation of the maximum power produced by a PV generator is very important to size a PV system(Amusat, Shodiya, and Ngadda 2020a). Many researchers have developed models to have a better understanding of PV modules. The models vary depending on the types of software researchers used, such as C-programming, Excel, Matlab / Simulink. However, Modeling and simulation of the PV module using Matlab/Simulink is widely used for studying characteristic curves(Amusat, Shodiya, and Ngadda 2020b).

Wafaa et al.(Abd et al. 2016) developed a Mathematical model for photovoltaic cells. A simple one diode mathematical model was implemented using Matlab script. The numerical values of the equivalent circuit parameters are generated by the program. The results revealed that the efficiency of solar cells has an inverse relationship with temperature while the irradiance levels are affected by the change of the photo-generation current and series resistance in the single diode model.

Zainab and Adel(Almukhtar and Merabet 2016) worked on maximum power point tracking based on estimated power for PV energy conversion systems. The MPPT strategy was built in Simulink and executed in an OPAL-RT real-time simulator through the RT-Lab software. The current and voltage to the circuit are measured and the signals to the converter are directed through the data acquisition pane.

Heng et al.(Li et al. 2014) designed an improved Newton-based stochastic extremum seeking MPPT controller. Several simulation and experimental results show the effectiveness of the proposed MPPT algorithm. Also, a light source driving photovoltaic MPPT system was adopted to evaluate the tracking performance of the proposed algorithm under the arbitrary desired irradiance.

Amusat et al.(Amusat et al. 2020a) developed a Mathematical model, and the authors used curve fitting tools to build P-V and I-V characteristics of the Solar Module. The developed model used manufacturer data under Standard Testing Conditions to predict the current, voltage, and power as well as the maximum current, voltage, and power.

The aim of this paper is to provide a quick method of generating maximum power from the PV characteristic curve using Matlab/Simulink.

\section{MATERIALS AND METHODS}

\section{The Materials}

The material used for this study is the manufacturer's specification of solar panel PS-P310-36 under STC in Table 1, Solar irradiance of $200,400,600,800$, and $1000 \mathrm{~W} / \mathrm{m}^{2}$, Cell temperature of $25^{\circ} \mathrm{C}$.

Tabel 1. Technical characteristics of the photovoltaic modules used for this model is shown in Table 1

\begin{tabular}{ll}
\hline Characteristic Value & Module \\
\hline Open Circuit Tension $\left(V_{o c}\right),[\mathrm{V}]$ & 42.9 \\
Short Circuit Current $\left(I_{s c}\right),[\mathrm{A}]$ & 9.31 \\
Maximum Rated Tension $\left(V_{\max }\right),[\mathrm{V}]$ & 36.3 \\
Maximum Rated Current $\left(I_{\max }\right),[\mathrm{A}]$ & 8.54
\end{tabular}


AMUSAT R. O. ET.AL

Maximum Power $\left(P_{\max }\right),[\mathrm{W}]$ 310

\section{Method}

The Mathematical equivalent circuit for the photovoltaic module in Figure 1 was developed under a Solar cell block which has already been built in the Matlab/Simulink library. For the Modeling and Simulation of the Photovoltaic cell Module type of PS-P310-36, equations (1- 7) were used to model the PV using input parameter $\left(I_{S C}\right.$ and $\left.V_{o c}\right)$ provided by the manufacturer under distinct Physical and environmental condition.

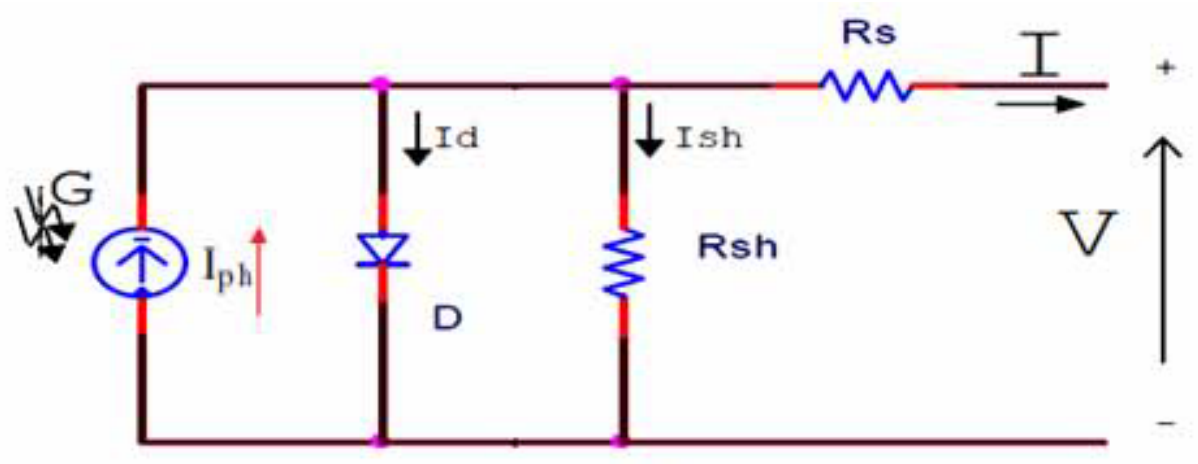

Figure 1. Equivalent Circuit of a Photovoltaic with one diode(Abd et al. 2016)

\section{Mathematical Modeling of PV Cell}

Solar cells are fabricated from a layer of semiconductors. A solar module is a connected assembly of one or more solar cells, packaged together for applications that require long life and high reliability. In turn, modules are connected together to produce solar arrays. The working principle of Solar cells is essentially based on the PV effect, which refers to the generation of a potential difference at the P-N junction in response to visible radiation(Ma et al. 2013).

\section{Ideal Photovoltaic Model}

An ideal photovoltaic cell can be represented by a light-generated current source $I_{p h}$ connected in parallel with a single diode, as shown in the equivalent circuit of Figure 1. The output current, I is denoted by equation (1)(Abd et al. 2016; Edouard and Njomo 2013).

$$
I=I_{p h}-I_{d}=I_{p h}-I_{o}\left(e^{\frac{q V}{K T}}-1\right)
$$

\section{Solar Cell Characteristic in Practice}

The solar cell (or circuit) contains series (Rs) and parallel (or shunt, Rsh) resistances. This made I-V characteristic of solar cells different from the ideal photovoltaic model in equation (1) and gave rise to a characteristic of the form shown in equation (2)(Edouard and Njomo 2013). 


$$
I=I_{p h}-I_{d}=I_{p h}-I_{o}\left(e^{\frac{q V}{K T}}-1\right)-I_{s h}
$$

Where

$$
I_{p h}=\left[I_{s c}+K_{i}\left(T_{r}-T_{o}\right) *\left(\frac{S}{1000}\right)\right]
$$

Equation (2) depends on the solar cell irradiance and cell's working temperature.

$$
I_{r s}=\frac{I_{s c}}{\left[\exp \left(\frac{q V_{o c}}{N_{s} A K T_{o}}\right)-1\right]}
$$

Equation 3 is the reverse saturate current at the reference temperature.

$$
I_{o}=I_{r s}\left(\frac{T_{o}}{T_{r}}\right)^{3} \exp \left[\frac{q * E_{g o}}{A K}\left(\frac{1}{T_{r}}-\frac{1}{T_{o}}\right)\right]
$$

Equation 4 is the diode saturated current, and it depends on the temperature.

$$
\begin{gathered}
\mathrm{I}_{\mathrm{pv}}=\mathrm{N}_{\mathrm{p}} * \mathrm{I}_{\mathrm{ph}}-\mathrm{N}_{\mathrm{p}} * \mathrm{I}_{0}\left[\exp \left(\frac{\mathrm{qV} \mathrm{pv}_{\mathrm{pv}}}{\mathrm{N}_{\mathrm{s}} \mathrm{AKT}}\right)-1\right] \\
P=\mathrm{I}_{\mathrm{pv}} * \mathrm{~V}_{\mathrm{pv}}
\end{gathered}
$$

Where

$I_{p h}$ : Photocurrent (Ampere)

$I_{s c}$ : Short-circuit current (Ampere)

$K_{i}$ : Cell "s short-circuit current temperature coefficient (Ampere /Kelvin)

$T_{o}$ : Cell operating temperature (Kelvin)

$T_{r}$ : Cell" is reference temperature in degree (Kelvin)

$S$ : Solar irradiance (Watt/meter square)

$I_{r s}:$ reverse saturation current of the diode

$q$ : Electron charge $\left(1.602 \times 10^{-19}\right.$ Coulomb)

$V_{o c}$ : Open circuit voltage (Volt)

$N_{p}$ : Cells interconnected in parallel (1)

$N_{s}$ : Cells interconnected in series (36)

$A$ : Ideality factor

$k$ : Boltzmann's constant $(1.38 \times 10-23$ Joule/Kelvin $)$

$T$ : the temperature of $\mathrm{p}-\mathrm{n}$ junction 
$I_{p v}$ : Output current of a PV module (A)

$I_{o}: \mathrm{PV}$ module saturated current (A)

$V_{p v}$ : Output voltage of a PV module (A)

$E_{g o}$ : band gap for silicon

\section{Quality of cell}

The short-circuit current and the open-circuit voltage are the maximum current and voltage, respectively from a solar cell. However, at both of these operating points, the power from the solar cell is zero. The "fill factor", more commonly known by its abbreviation "FF", is a parameter that, in conjunction with $\mathrm{V}_{\mathrm{oc}}$ and $\mathrm{I}_{\mathrm{sc}}$, determines the maximum power from a solar cell. By construction, the empirically measured power is bounded by the theoretical power based on short and open circuit arguments: $\mathrm{P}_{\max }<\mathrm{V}_{\mathrm{oc}} \mathrm{I}_{\mathrm{sc}}$. The gap between the left-hand side and right-hand side can be measured by the Fill factor (FF) (4).

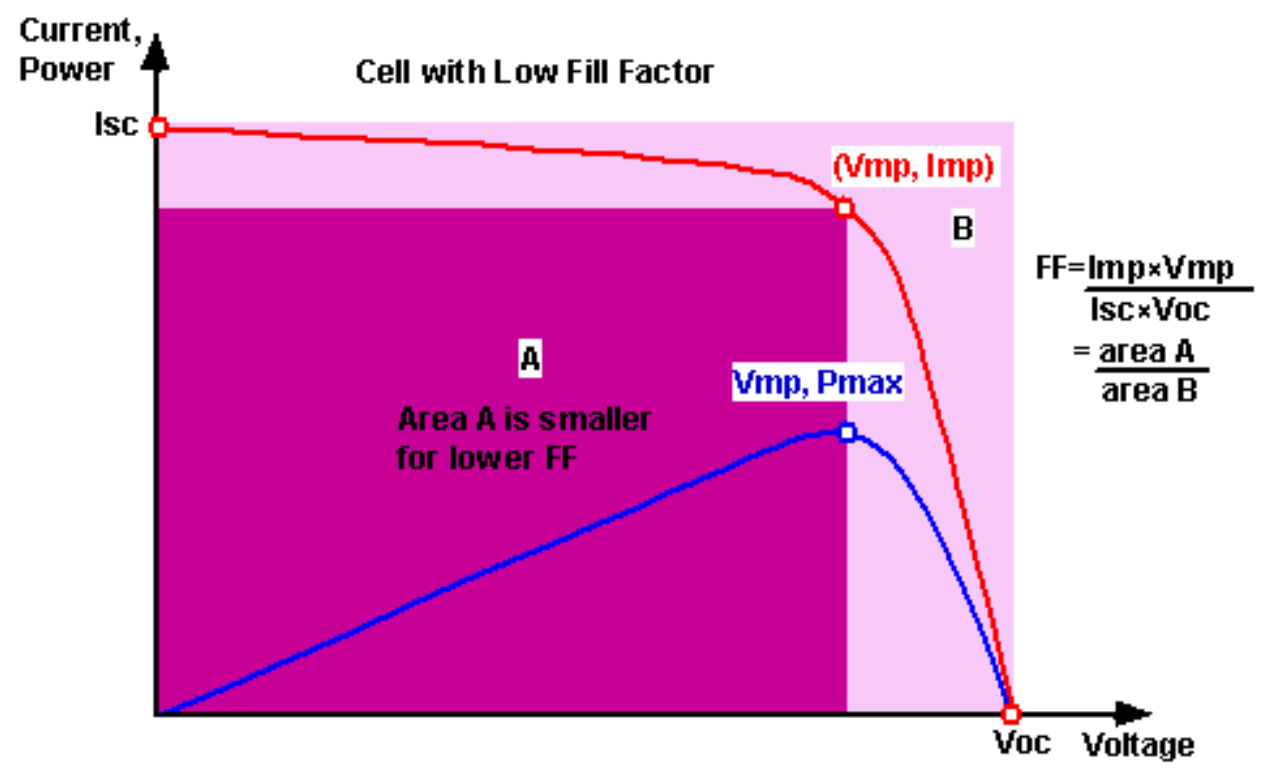

Figure 2. Photovoltaic characteristics showing the fill factor (14)

The FF is defined as the ratio of the maximum power from the solar cell to the product of $\mathrm{V}_{\mathrm{oc}}$ and $\mathrm{I}_{\mathrm{sc}}$ So that:

$$
F F=\frac{P_{\max }}{V_{o c} I_{s c}}=\frac{V_{m p} I_{m p}}{V_{o c} I_{s c}}
$$

\section{Panel Efficiency}

The efficiency $\eta$ of the module is the ratio of output power to input power: 


$$
\eta=\frac{P_{\max }}{P_{\text {in }}}
$$

avoid calculation complexities of irradiance, the Standard Testing Conditions (STC) are specified as AM 1.5 with an irradiance of $\mathrm{E}=1000 \mathrm{~W} / \mathrm{m}^{2}$ under 25 Celsius. For a given irradiance level $\mathrm{E}$ and a module, the solar (input) power $\left(\mathrm{P}_{\text {in }}\right)$ falling on to the module is defined as(Chaudhary and Maheshwari 2013).

$$
P_{\text {in }}=A X E
$$

where $A$ is the area of the panel.

\section{Simulink PV Model}

Figure 3 shows the formation of the proposed system, which consists of the signal builders, repeating sequence, scope, and worksheet.

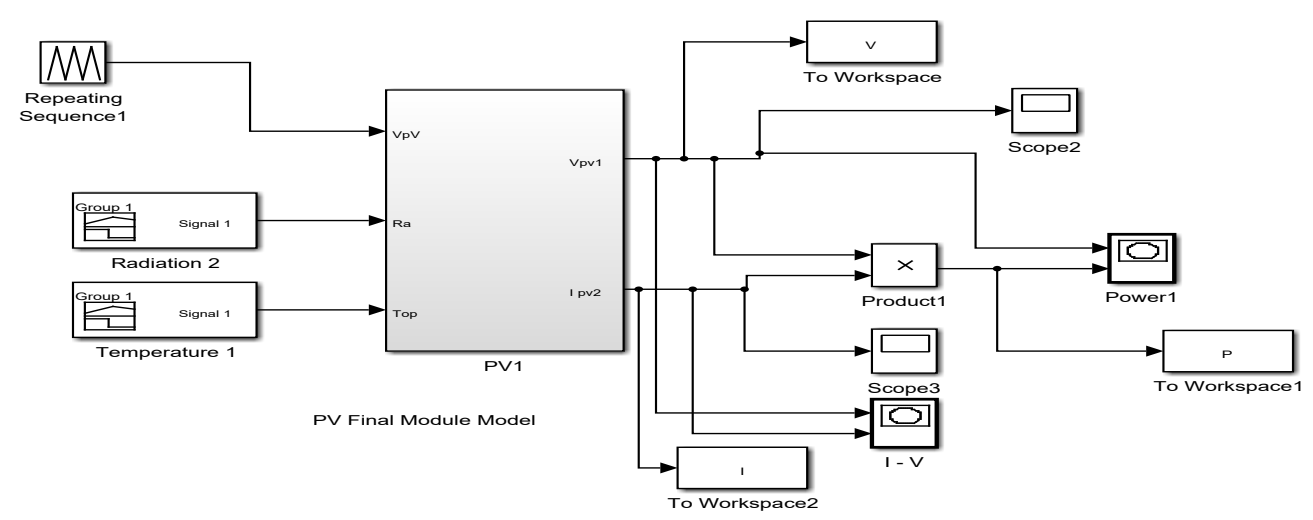

Figure 3. PV Model

\section{THE RESULTS AND DISCUSSION}

The result of the PV model developed was based on mathematical equations (1-7)(Edouard and Njomo 2013) and the input parameter provided by the manufacturer under the varying intensity of irradiance $\left(200 \mathrm{~W} / \mathrm{m}^{2}, 400 \mathrm{~W} / \mathrm{m}^{2} 600 \mathrm{~W} / \mathrm{m}^{2}, 800 \mathrm{~W} / \mathrm{m}^{2}\right.$, and $\left.1000 \mathrm{~W} / \mathrm{m}^{2}\right)$ and constant temperature of $25^{\circ} \mathrm{C}$ are shown in Figures $4-13$. The PV cell temperature at STC was maintained, and the irradiance is varied at decreasing intervals of $200 \mathrm{~W} / \mathrm{m}^{2}$ with the aid of signal builder from $1000 \mathrm{~W} / \mathrm{m}^{2}$ to $200 \mathrm{~W} / \mathrm{m}^{2}$. The results for I $-\mathrm{V}$ and $\mathrm{P}-\mathrm{V}$ characteristics curves of the module depicted the four most cogent points $\left(\mathrm{V}_{\mathrm{mp}}, \mathrm{P}_{\mathrm{mp}}, \mathrm{V}_{\mathrm{oc}}\right.$, and $\left.\mathrm{I}_{\mathrm{sc}}\right)$, a good agreement in term of short circuit current, open-circuit voltage, and maximum power, respectively with respect to previous similar PV studies(Bonkoungou, Koalaga, and Njomo 2013; Panchal and Jolly 2013).

Figure 4 is the P-V arve of a PV module at STC. The maximum power output of the simulated model is $308 \mathrm{~W}$. 
AMUSAT R. O. ET.AL

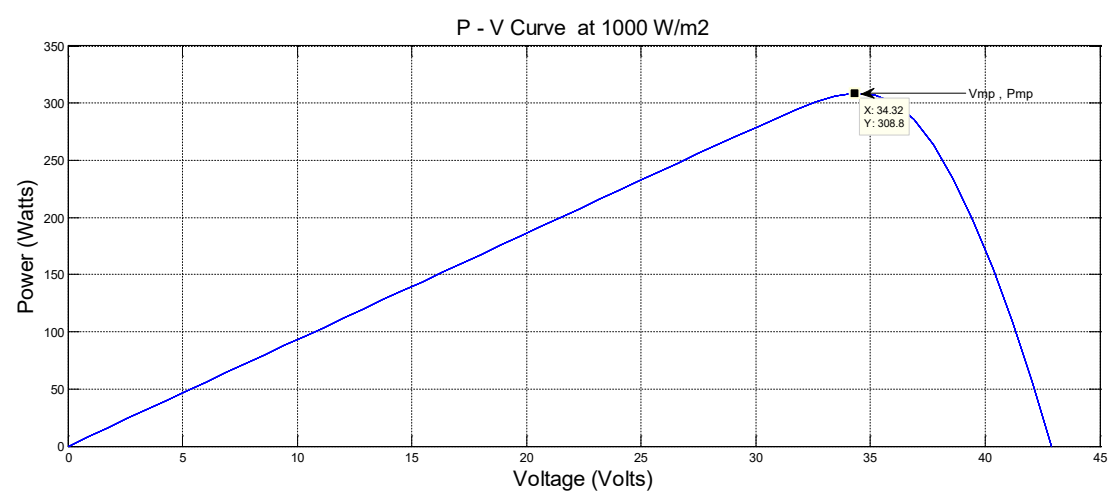

Figure 4. P - V curve adjusted to single remarkable point at STC

Figure 5 shows the I-V output characteristics of the PV module at STC. The I-V curve showed that the short circuit current and open-circuit voltage are 8.997 A and 34.32 V' respectively.

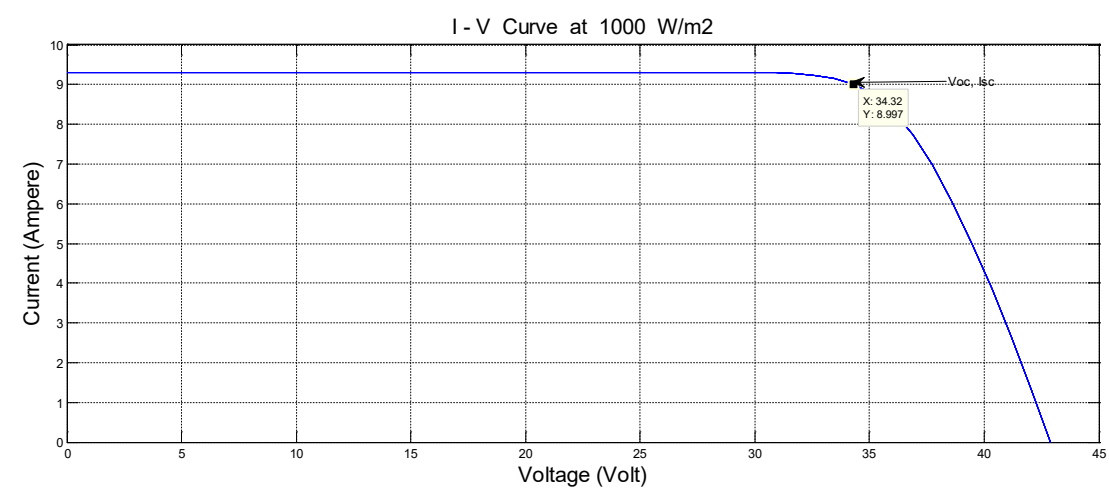

Figure 5. I - V curve adjusted to single remarkable point at STC

Figure 6 is the P-V curve of a PV module for irradiance of $800 \mathrm{~W} / \mathrm{m}^{2}$ at constant temperature $25^{\circ} \mathrm{C}$. The maximum power output of the simulated model is $251.6 \mathrm{~W}$.

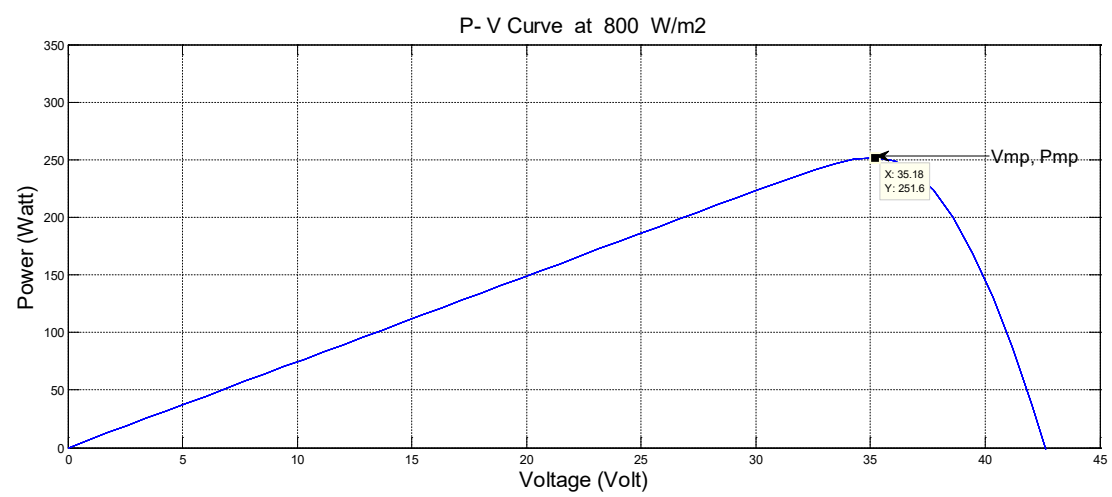

Figure 6. P - V curve adjusted to single remarkable point at $25^{\circ} \mathrm{C}$ 
Figure 7 shows the I-V output characteristics of the PV module for irradiance $800 \mathrm{~W} / \mathrm{m}^{2}$ at constant temperature $25^{\circ} \mathrm{C}$. The I-V curve showed that the short circuit current and open-circuit voltage are 7.294 A and 34.32 V' respectively.

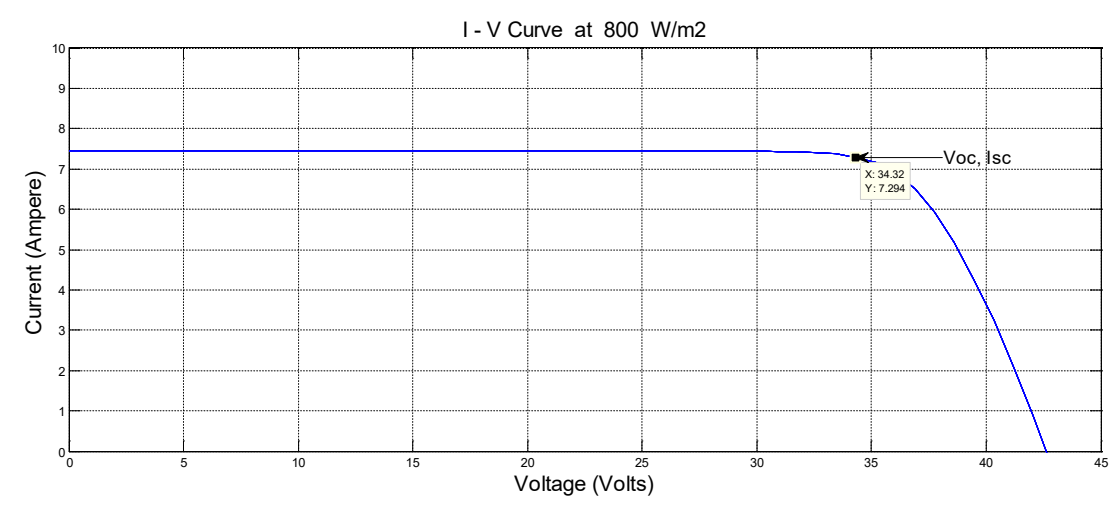

Figure 7. I - V curve adjusted to single remarkable point at $25^{\circ} \mathrm{C}$

Figure 8 is the $\mathrm{P}-\mathrm{V}$ curve of a $\mathrm{PV}$ module for irradiance of $600 \mathrm{~W} / \mathrm{m}^{2}$ at constant temperature $25^{\circ} \mathrm{C}$. The maximum power output of the simulated model is $191.4 \mathrm{~W}$.

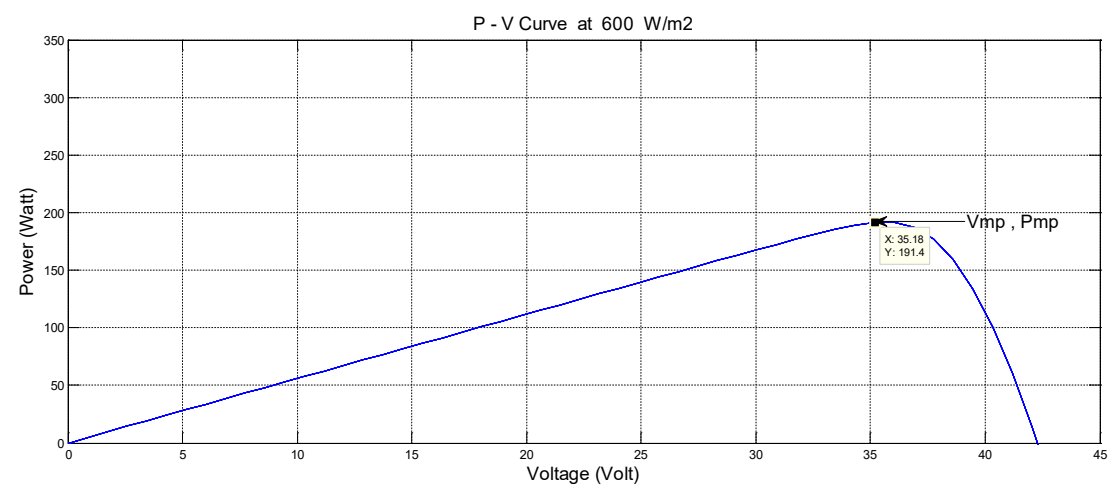

Figure 8. $\mathrm{P}-\mathrm{V}$ curve adjusted to single remarkable point at $25^{\circ} \mathrm{C}$

Figure 9 shows the I-V output characteristics of the PV module for irradiance $600 \mathrm{~W} / \mathrm{m}^{2}$ at constant temperature $25^{\circ} \mathrm{C}$. The I-V curve showed that the short circuit current and open-circuit voltages are $5.44 \mathrm{~A}$ and $35.18 \mathrm{~V}$. 
AMUSAT R. O. ET.AL

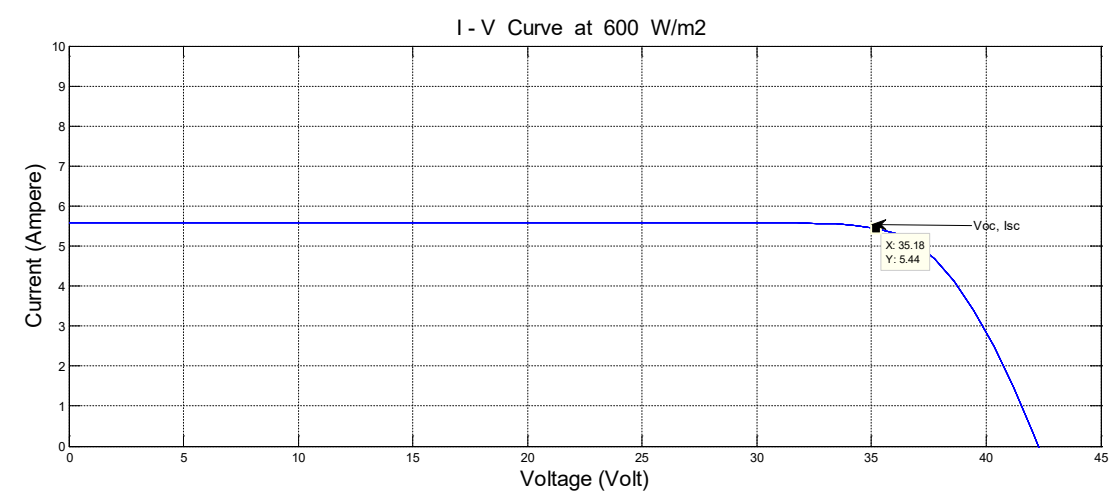

Figure 9. I - V curve adjusted to single remarkable point at $25^{\circ} \mathrm{C}$

Figure 10 is the P-V curve of a PV module for irradiance of $400 \mathrm{~W} / \mathrm{m}^{2}$ at constant temperature $25^{\circ} \mathrm{C}$. The maximum power output of the simulated model is $129.2 \mathrm{~W}$.

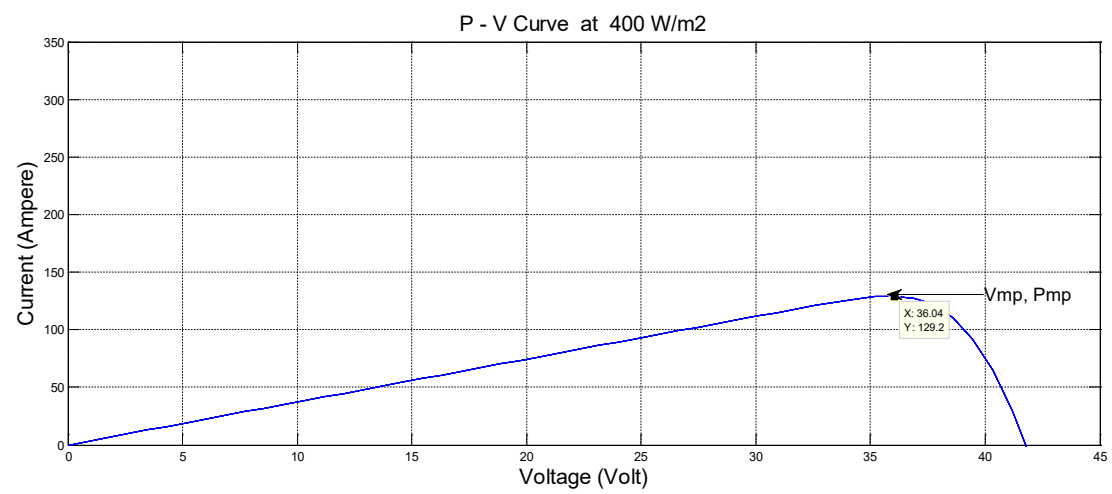

Figure 10. $\mathrm{P}-\mathrm{V}$ curve adjusted to single remarkable point at $25^{\circ} \mathrm{C}$

Figure 11 shows the I-V output characteristics of PV module for irradiance $600 \mathrm{~W} / \mathrm{m}^{2}$ at constant temperature $25^{\circ} \mathrm{C}$. The I-V curve showed that the short circuit current and open-circuit voltage are $3.586 \mathrm{~A}$ and $36.04 \mathrm{~V}$.

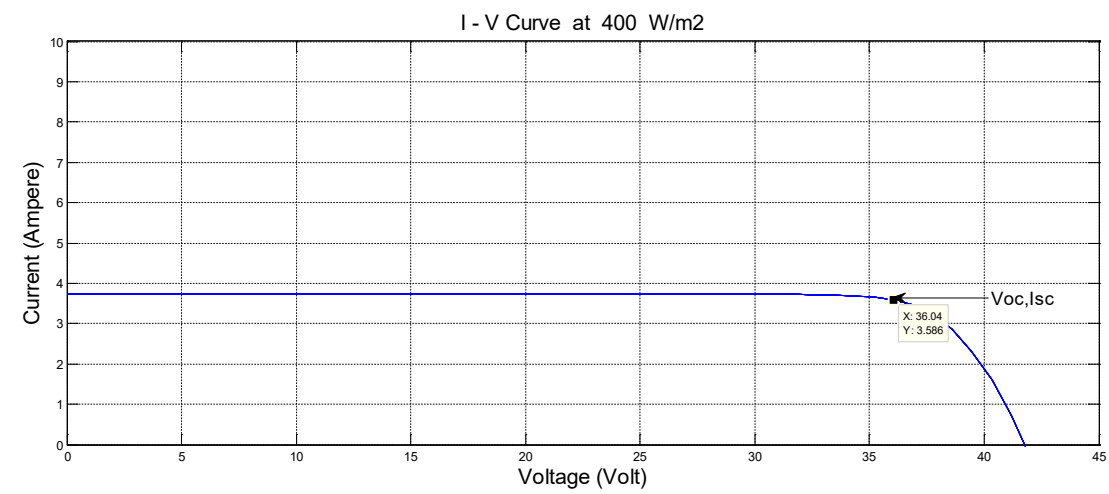

Figure 11. I - V curve adjusted to single remarkable point at $25^{\circ} \mathrm{C}$ 
Figure 12 is the P-V arre of a PV module for irradiance of $200 \mathrm{~W} / \mathrm{m}^{2}$ at constant temperature $25^{\circ} \mathrm{C}$. The maximum power output of the simulated model is $6474 \mathrm{~W}$.

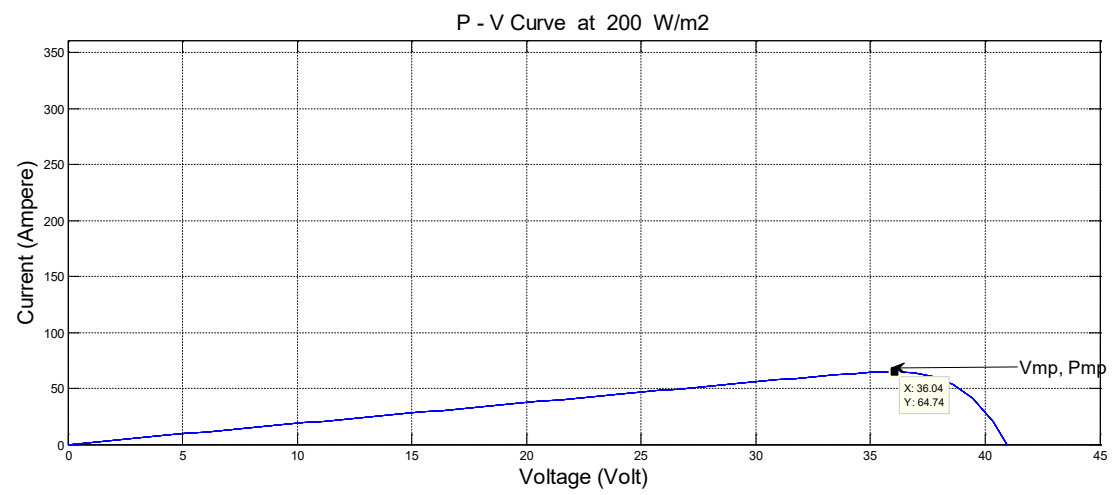

Figure 12. I - V curve adjusted to single remarkable point at STC

Figure 13 shows the I-V output characteristics of PV module for irradiance $200 \mathrm{~W} / \mathrm{m}^{2}$ at constant temperature $25^{\circ} \mathrm{C}$. The I-V curve showed that the short circuit current and open-circuit voltages are $1.82 \mathrm{~A}$ and $35.18 \mathrm{~V}$ ' respectively.

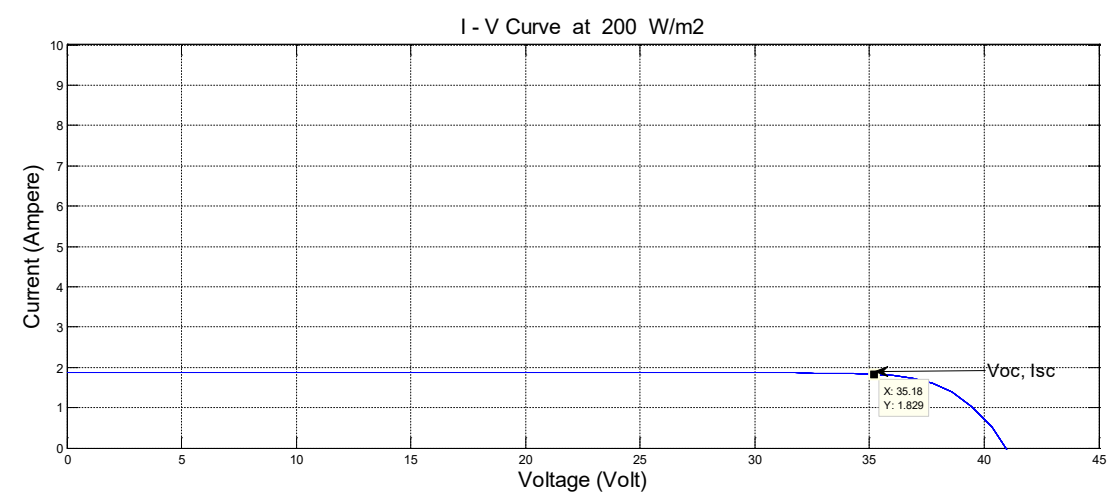

Figure 13. I - V curve adjusted to single remarkable point at $25^{\circ} \mathrm{C}$

\section{CONCLUSION}

The PV model developed was based on PV Mathematical equations, the electrical features of PV provided by the manufacturer, and environmental parameters (Radiation and Temperature). The I $-\mathrm{V}$ and $\mathrm{P}-\mathrm{V}$ curves were obtained from the simulation of the PV module developed under MATLAB/Simulink interface using inbuilt blocks in Matlab/Simulink. The results obtained showed reasonable agreement with the previous similar researchers of the PV models. The model is said to stand as a quick tool for the designers in predicting PV characteristic aurves and also serve as a pre-assessment of the maximum power of the PV system. 


\section{REFERENCES}

Abd, Wafaa, E. L. Basit, Ashraf Mosleh, A. B. D. El, Fouad Abd, El Moniem, and Saad Soliman. 2016. "Mathematical Model for Photovoltaic Cells." Journal of Sciences (23):1-13.

Almukhtar, Zainab, and Adel Merabet. 2016. "Maximum Power Point Tracking Based on Estimated Power for PV Energy Conversion System." 10(4):533-37.

Amusat, R. O., Sulaimon Shodiya, and Y. H. Ngadda. 2020a. "Mathematical Modeling of Maximum Power of Solar Photovoltaic Systems and Regression Analysis for Field Test Conditions." Nigeria Journal of Engineering Science and Technology Research 6(1):104-11.

Amusat, R. O., Sulaimon Shodiya, and Y. H. Ngadda. 2020b. "Pre-Assessment Model of Solar Photovoltaic Module Using User-Friendly Matlab Program.” Journal of Science Technology and Education 8(4):132-39.

Bonkoungou, Dominique, Zacharie Koalaga, and Donatien Njomo. 2013. "Modelling and Simulation of Photovoltaic Module Considering Single-Diode Equivalent Circuit Model in MATLAB." International Journal of Emerging Technology and Advanced Engineering 3(3):493-502.

Chaudhary, Puneet Kumar, and Ranjan Maheshwari. 2013. "A Critical Review on Photovoltaic Base Maximum Power Generation System." International Journal of Recent Technology and Engineering (IJRTE) 1(6):51-62.

Edouard, Mboumboue, and Donatien Njomo. 2013. "Mathematical Modeling and Digital Simulation of PV Solar Panel Using MATLAB Software." International Journal of Emerging Tecnology and Advanced Engineering 3(9):24-32.

Garba, A. A., R. O. Amusat, and Y. H. Ngadda. 2016. "Estimation of Global Solar Radiation Using Sunshine -Based Model in Maiduguri, North East, Nigeria." Applied Research Journal 2(1):1926. doi: magiran.com/p1481948.

Li, Heng, Jun Peng, Weirong Liu, Zhiwu Huang, and Kuo Chi Lin. 2014. "A Newton-Based Extremum Seeking MPPT Method for Photovoltaic Systems with Stochastic Perturbations." International Journal of Photoenergy 2014. doi: 10.1155/2014/938526.

Ma, Jieming, Ka Lok Man, T. O. Ting, Nan Zhang, Sheng Uei Guan, and Prudence W. H. Wong. 2013. "Approximate Single-Diode Photovoltaic Model for Efficient I-V Characteristics Estimation." The Scientific World Journal 2013. doi: 10.1155/2013/230471.

Madu, Madu, Sulaimon Shodiya, and Abdulraheem Toyin. 2018. "Solar Radiation Potential for Electricity Generation in Potiskum.” ATBU, Journal of Science, Technology \& Education (JOSTE) 6(2):135-41.

Panchal, Rutvi Rohit, and Lochan Jolly. 2013. "Optimization of Silicon Solar Cell in MATLAB/SIMULINK for Improved Efficiency.” International Journal of Management \& Information Technology 5(3):576-85. doi: 10.24297/ijmit.v5i3.758.

Shodiya, Sulaimon, Luqman R, Ngala G. M., Oumarou M. B., and Muhammad A. B. 2016. "PreAssessment Models of Global Solar Radiation Using Sunshine Duration in Maiduguri." ATBU Journal of Science, Technology and Education 4(1):174-78. 